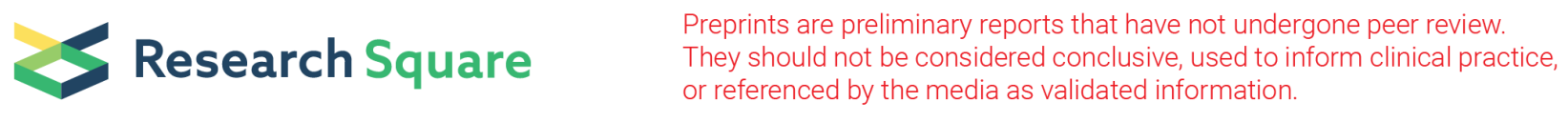

\title{
Bioindication of Heavy Metals in a Waterfall Outflow Using a Bryophyte Community
}

\author{
Narin Printarakul \\ Chiang Mai University \\ Weeradej Meeinkuirt ( $\nabla$ weeradej.mee@mahidol.ac.th ) \\ Mahidol University
}

\section{Research Article}

Keywords: Bryophyte community, Scopelophila cataractae, Stream ecosystem, Doi Suthep-Pui National Park, Enrichment factor

Posted Date: December 14th, 2021

DOl: https://doi.org/10.21203/rs.3.rs-967396/v1

License: (c) (i) This work is licensed under a Creative Commons Attribution 4.0 International License. Read Full License 


\section{Abstract}

Huay Pah Lahd stream in Doi Suthep-Pui National Park, Thailand, is potentially vulnerable to nearby anthropogenic activities. In this study, we determined heavy metal accumulation in bryophyte tissue and their growth substrates. Enrichment factors (EFs) of heavy metals were employed to monitor concentrations in bryophyte tissue. Of eight bryophyte taxa investigated, Scopelophila cataractae showed the highest capacity to accumulate metals in tissue, particularly Fe, Zn, Cd and Cu in protonemata (8,026.7, 1,187.2, 16.9 and $530.1 \mathrm{mg} \mathrm{kg}^{-1}$, respectively). Furthermore, the endangered and rare bryophyte taxa S. cataractae and Porella acutifolia were found intermingled with other urban and common aquatic bryophytes. These taxa might be considered sensitive warning organisms for heavy metal stress in stream ecosystems induced by environmental pollution. Because EFs of all heavy metals were $<2$, this suggests that natural processes are the key source of heavy metals; furthermore, the environment of this National Park was identified as being heathy, and an important ecosystem buffer and biodiversity haven.

\section{Introduction}

A number of heavy metals in soil and water (e.g., zinc (Zn), copper (Cu), iron (Fe), etc.) are essential for growth and reproduction of biota. However, other metals and metalloids (e.g., cadmium (Cd), arsenic (As), mercury ( $\mathrm{Hg}$ ) etc.), even when present in low quantities in the growth medium, can adversely affect organism development, homeostasis, metabolism and reproduction. Numerous studies have found that hazardous metallic elements have the ability to affect biota in terrestrial ecosystems via the food chain and bioaccumulation ${ }^{1}$.

In freshwater habitats, exposure to heavy metals and other contaminants results in a range of negative impacts, including loss of aquatic biota and ecosystem alterations ${ }^{2}$. On the other hand, many output streams from waterfalls have been reported to have low heavy metal contamination as they are located primarily in highland national parks or other parcels of land designated as protected by governments. The physical condition of a waterfall habitat, which has a high velocity and volume of water, can dilute heavy metal concentrations. In many locations, however, rapid development in the tourism industry and various anthropogenic activities along waterfall streams have resulted in elevated concentrations of heavy metals in waterfall ecosystems in recent years ${ }^{3}$.

Bryophytes are significant species in aquatic and related terrestrial ecosystems, especially those where heavy metal concentrations have been elevated from anthropogenic sources. Heavy metals can be absorbed and accumulated by bryophytes through their surfaces from growth media such as soil and rock. Scopelophila cataractae (Mitt.) Broth. (Pottiaceae), for example, experiences high tolerance and accumulation of $\mathrm{Cd}$ and $\mathrm{Cu}^{4}$. Mosses and liverworts have been identified as ecological bioindicators of a variety of pollution sources and environmental changes ${ }^{5}$. This implies that the presence of certain bryophyte taxa may be used to monitor the ecological status of harsh environments.

In this study, we explore bryophyte communities and heavy metal accumulation capabilities of bryophytes found in the outflow from the Pah Lahd waterfall, Doi Suthep-Pui National Park, Thailand. This National Park is adjacent to the city of Chiang Mai, and is likely subject to anthropogenic activities such as stream pollution. To evaluate heavy metals potentially available to plants from surface soil and to determine the contamination level of each metal for use in monitoring anthropogenic pollution in the study site, enrichment factors (EFs) were used.

\section{Methods}

Study site. Doi (Mountain) Suthep, Doi Suthep-Pui National Park, Thailand, has several waterfalls. Tourist activities have grown recently in the area of the Huay Pah Lahd waterfall. On the eastern slope of Doi Suthep at c. 580-660 m elevation (18 ${ }^{\circ} 47 \bar{c} 56.0 \mathrm{c}$ $\zeta \mathrm{N}, 98^{\circ} 55 \mathrm{c} 52.0 \zeta \overline{\mathrm{E}}$ ), the waterfall is surrounded by mixed evergreen/deciduous forest, small villages and tourist activities. The water depth in the stream ranges from 0.2 to $0.6 \mathrm{~m}$. In 2020 total annual rainfall, mean relative humidity and mean temperature in Chiang Mai Province were approximately $1,085.1 \mathrm{~mm}$., $63.4 \%$ and $27.6{ }^{\circ} \mathrm{C}$, respectively. Anthropogenic activities are thought to be a major cause of water pollution in the waterfall streams. 
Collection of plant, sediment and water samples.The field excursion was done on June 15, 2020, after receiving authorization from Department of National Parks, Wildlife, and Plant Conservation of Thailand. All bryophyte specimens were collected in Huay Pah Lahd streams with a plastic spatula on wet rocks and the thin soil layer above the rock, which are the substrates for all bryophyte taxa. Individual plant samples were stored in clean plastic bags, labeled, and transported to the laboratory in ice-filled box as quickly as possible. Plant tissue was rinsed with deionized (DI) water for 30 s to remove excess soil, visible debris, fine stones and pebbles, loosely attached mineral particles, and tiny organic materials, then air-dried at room temperature and stored at $4^{\circ} \mathrm{C}$ until required ${ }^{44}$. The plant material used in this study was formally identified by Narin Printarakul. Dried plant specimens were preserved and deposited in the Chiang Mai University (CMUB) Herbarium, which is a publicly accessible herbarium at Chiang Mai University, i.e. H. involuta (Printanakul N. 15062020_1);S. cataractae; (Printanakul N. 15062020_2); Bryum sp. (Printanakul N. 15062020_3); F. crispulus var. crispulus (Printanakul N. 15062020_4); C. prionophyllum (Printanakul N. 15062020_5) E. zollingeri (Printanakul N. 15062020_6); M. emarginata var. emarginata (Printanakul N. 15062020_7); P. acutifolia var. birmanica (Printanakul N. 15062020_8).

Bryophyte taxa identification and morphological characteristics were investigated using Olympus stereo (SZ-30) and compound (Eclipse E-200) microscopes. The distinctive characteristics of bryophyte taxa were illustrated with light microscope (LM) photographs by using a Nikon (D7000) camera. Taxonomic identification of bryophyte taxa was via Eddy ${ }^{24}$, Eddy ${ }^{45}$, Gradstein ${ }^{46}$, Hattori ${ }^{23}$, Li et al. ${ }^{20}$, Wu et al. ${ }^{29}$ and Zhang and $\mathrm{He}^{47}$.

Soil samples were collected under bryophyte patches with a plastic spatula. A water sample was collected from a stream near the plant specimens in a $1 \mathrm{~L}$ polyethylene bottle and stored in an ice-filled container $\left(4^{\circ} \mathrm{C}\right)$. In the field, pieces of rocks under bryophyte patches (only S. cataractae and P. acutifolia var. birmanica) were crushed to small sizes using a hammer. The rock materials were stored in self-locking polythene bags and sealed in double bags before being transported to the laboratory. All the plant experiments were carried out in accordance with relevant institutional, national, and international guidelines and legislation.

Physicochemical properties of water sample. During the sampling period,selected environmental parameters in the water sample were analyzed using the methodologies provided in APHA, AWWA, and WEF ${ }^{48}$, e.g., total solids, total hardness, $\mathrm{NO}_{3}-\mathrm{N}$, $\mathrm{NH}_{3}-\mathrm{N}, \mathrm{TKN}, \mathrm{PO}_{4}, \mathrm{~S}^{2-}$, and $\mathrm{BOD}_{5}$. Furthermore, TOC was determined using a TOC analyzer (multi N/C 2100/2100s, Analytik Jena, Germany), fluoride $\left(\mathrm{F}^{-}\right)$concentration with an ion selective electrode (Thermo Scientific, ORION STAR A324), and chloride ( $\mathrm{Cl}^{-}$) with a Dionex ICS-900 ion chromatograph (Thermo Fisher Inc., Japan). Fifty $\mathrm{mL}$ of the water sample were passed through a cellulose membrane filter, $0.45 \mathrm{~mm}$ pore size, and then acidified with $0.05 \mathrm{~mL}$ double-distilled hydrochloric acid $\left(\mathrm{HCl}, \mathrm{Merck}^{\mathrm{O}}\right)$ to $\mathrm{pH}<2$. Heavy metals (i.e., $\mathrm{Cd}, \mathrm{Cu}, \mathrm{Ni}, \mathrm{Cr}, \mathrm{Zn}, \mathrm{Pb}, \mathrm{Fe}$, and $\mathrm{Mn}$ ) were determined by flame atomic absorption spectrophotometry (FAAS; AAnalyst200, PerkinElmer ${ }^{\circledR}$ ).

Water temperature and dissolved oxygen (DO) level were determined with a DO meter (HI 9147, Hanna Instruments, USA), pH with a LAB 850 set pH meter (Accumetâ AP115, USA), and water depth with a wooden ruler (2 m). Air temperatures at the sampling site were determined at the same time of water sampling with a digital thermometer.

Heavy metals analysis. Plant and soil samples were dried at $70^{\circ} \mathrm{C}$ for 3 days. Each sample was finely powdered to pass through a 250-mm mesh using an IKA mill. Rocks were dried at $110^{\circ} \mathrm{C}$ for $24 \mathrm{~h}$ and then ground to a powder using an abrasion testing machine. The crushed rocks were then sieved using a 75-mm mesh sieve. Plant material was placed in a vessel tube and digested with aqua regia (conc. $70 \% \mathrm{HNO}_{3}: 37 \% \mathrm{HCl}=1: 3$ ); the soil sample was digested with conc. $70 \% \mathrm{HNO}_{3}$ and $30 \%$ hydrogen peroxide $\left(\mathrm{H}_{2} \mathrm{O}_{2}\right)$; and fine crushed stones were digested with nitric acid $\left(\mathrm{HNO}_{3}\right.$, Merck $^{\mathrm{O}}$, Germany, TraceMetal ${ }^{\mathrm{TM}}$ grade) at different temperatures following the methods of APHA, AWWA, and WEF ${ }^{48}$. Digests were filtered through Whatman number 42 filter paper and brought to $25 \mathrm{~mL}$ with $1 \% \mathrm{HNO}_{3}$ (TraceMetal ${ }^{\mathrm{TM}}$ grade). The water sample was filtered with a 0.45 -mm membrane filter. Heavy metals (i.e., $\mathrm{Cd}, \mathrm{Cu}, \mathrm{Ni}, \mathrm{Cr}, \mathrm{Zn}, \mathrm{Pb}, \mathrm{Fe}$, and $\mathrm{Mn}$ ) were determined using FAAS. All standards were prepared with deionized (DI) water (resistivity $18.2 \mathrm{~mW} \mathrm{~cm}$ at $25^{\circ} \mathrm{C}$, Simplicity UV system, Millipore ${ }^{\circ}$ ). Each sample was tested in triplicate and blank solutions were analyzed using identical methods in order to evaluate errors in analytical measurements. Standard test solutions were also analyzed after every 20 samples in order to obtain accurate, precise and reproducible results. NIST SRM ${ }^{\circledR}$ 
2710a Montana soil, JB-3 (basalt), and NIST SRM ${ }^{\circledR} 1515$ apple leaves were used as soil, rock and plant standard reference materials, respectively, for method validation. Percentage recoveries for the soils and plant materials were in the range of 98.2$108.3 \%, 94.3-100.7 \%$, and $101.4-103.3 \%$ for different heavy metals, respectively. The relative standard deviation (RSD) ranged from $1.13-4.03 \%, 1.32-4.01 \%$ and $1.23-3.98 \%$ for soil, rock and plant materials, respectively.

Data analyses. Enrichment factors ( $E F s)$ are used to assess the levels of an element potentially available to bryophytes from soil, and also to evaluate the contribution to metal content in bryophyte tissues from anthropogenic sources. It is calculated as follows, using the example of Fe:

$E F s=\left(\mathrm{C}_{\mathrm{n}} / \mathrm{C}_{\mathrm{Fe}}\right)_{\text {plant }} /\left(\mathrm{C}_{\mathrm{n}} / \mathrm{C}_{\mathrm{Fe}}\right)_{\text {soil }}$

Where $\mathrm{C}_{\mathrm{n}}$ is the concentration of the metal ' $\mathrm{n}$ ' in bryophyte or soil samples, and $\mathrm{C}_{\mathrm{Fe}}$ is the concentration of Fe determined before exposure. As proposed by Macedo-Miranda et al. ${ }^{49}, E F$ is classified into four categories, $E F £ 1$, no contamination; $3<E F<5$, slight contamination; $6<E F £$, moderate contamination; and $E F^{3} 10$, highly contamination.

On a Windows-based PC, statistical analysis was performed using SPSS ${ }^{\circledR}$ (SPSS, Chicago, IL). To identify significant differences in mean values, a one-way ANOVA and least significant difference (LSD) post hoc comparison were employed.

\section{Results And Discussion}

Physicochemical properties of waterfall stream. Table 1 shows the results of the environmental parameters of the Huay Pah Lahd stream. Rainfall strongly affects physicochemical properties of the water because velocity, depth, and level increased, and nutrient run-off (and/or pollution run-off) changed during the sampling period in the rainy season. The water at the sampling site is shallow $(0.4-1 \mathrm{~m})$. Temperatures in water samples range from $20^{\circ} \mathrm{C}$ to $33^{\circ} \mathrm{C}$, while water temperature along the bank of Pharadorn waterfall, located downstream of Romklao waterfall in Phu Hin Rong Kla National Park, is $25^{\circ} \mathrm{C}^{6}$. Low water temperature and low light intensity are important for bryophyte development and primary productivity; however, nutrient enrichment in plant media (e.g., soil, sediment) is the most important component for bryophyte growth ${ }^{7}$.

The quantities of nutrients such as ammonia-nitrogen $\left(\mathrm{NH}_{3}-\mathrm{N}\right)$, nitrate-nitrogen $\left(\mathrm{NO}_{3}-\mathrm{N}\right)$, total Kjeldahl nitrogen $(\mathrm{TKN})$ and phosphate $\left(\mathrm{PO}_{4}\right)$ were below detectable levels, i.e., $1.01 \mathrm{mg} \mathrm{L}^{-1},<4.0 \mathrm{mg} \mathrm{L}^{-1}$, and $0.02 \mathrm{mg} \mathrm{L}^{-1}$, respectively. Increased concentrations of phosphorus and nitrogen compounds, which are limiting factors and essential nutrients for aquatic life, can cause eutrophication. However, dilution effects during the rainy season in lotic ecosystems is a key factor in causing low nutrient concentrations in water bodies ${ }^{8}$. Heavy metal concentrations $(\mathrm{Cu}, \mathrm{Cd}, \mathrm{Zn}, \mathrm{Fe}, \mathrm{Cr}, \mathrm{Pb}$ and $\mathrm{Mn}$ ) in the water sample were relatively low to undetectable except for $\mathrm{Ni}$, which was detected at $0.056 \mathrm{mg} \mathrm{L}^{-1}$. Furthermore, $\mathrm{F}^{-}$and $\mathrm{Cl}^{-}$contents were $<0.15$ and $6.2 \mathrm{mg} \mathrm{L}^{-}$ 1 , respectively, which are considered low according to the permissible limits set by the World Health Organization (WHO) at 0.6$1.5 \mathrm{mg} \mathrm{L}^{-1}$ and $250 \mathrm{mg} \mathrm{L}^{-1}$, respectively ${ }^{9}$. Total organic carbon (TOC) content of the water sample is below the detection limit (< $\left.0.05 \mathrm{mg} \mathrm{L}^{-1}\right)$, which is due to the low content of contaminants in the water sources ${ }^{10}$.

Total solids is a direct measurement of the total mass of organic and inorganic particles suspended in water, as well as total dissolved ions in the water ${ }^{11}$. A high total solid content in waters is the most likely cause of increased total hardness. Other possible sources of increased hard water content include $\mathrm{Ca}, \mathrm{Mg}$ and other heavy metals widely distributed in rocks and sediments ${ }^{12}$. Pah Lahd stream is naturally soft in this study $\left(31.7 \mathrm{mg} \mathrm{L}^{-1}\right)$ because it has very low amounts of total solids and minerals. Soft water is defined as having a low amount of calcium carbonate in the water sample ${ }^{13}$.

In this study, the pH value of the stream was near neutral (6.75). Slightly acidic water ( pH 5-6) occurs naturally, enabling some heavy metals that are adsorbed to mineral surfaces to be dissolved in aquatic ecosystems, as well as enhancing mineral dissolution in sediment ${ }^{14}$. However, in this investigation, slightly acidic water ( $\mathrm{pH}$ 6.5-6.9) was not shown to be detrimental to aquatic biota or the ecosystem. The DO level of the study site $\left(5.03 \mathrm{mg} \mathrm{L}^{-1}\right)$ was nearly equivalent to the DO water quality standard in a Thai waterfall stream $\left(6 \mathrm{mg} \mathrm{L}^{-1}\right)$; nevertheless, a reduction in DO levels might be linked to human activities, i.e., the presence of relatively large numbers of tourists and improper waste disposal ${ }^{15}$. High flow velocity and turbulence of a waterfall 
increases DO content ${ }^{16}$. Biological oxygen demand (BOD) is another important indicator of water quality, as it measures the quantity of oxygen required for microbial respiration and biological degradation of organic matter in water. Reduced BOD levels imply that the quantity of organic substances is promoting the growth of microbial populations, thus enhancing the available DO content for aquatic life. The current study revealed that the water sample had a low BOD level $\left(<1 \mathrm{mg} \mathrm{L}^{-1}\right)$, indicating that the waterfall ecosystem had good water quality ${ }^{17}$.

Bryophyte taxa in the study site. Based on their microhabitats and life modes, a total of eight bryophytes were collected from two major taxonomic groupings i.e., (1) moss: epilithic bryophytes or rupicolous (three acrocarpous mosses: Hyophila involuta (Hook.) A. Jaeger (Pottiaceae), S. cataractae and Bryum sp. (Bryaceae); and three aquatic mosses (one acrocarpous moss, Fissidens crispulus Brid. var. crispulus (Fissidentaceae) and two pleurocarpous mosses: Claopodium prionophyllum (Müll. Hal.) Broth. (Leskeaceae), and Ectropothecium zollingeri (Müll. Hal.) A. Jaeger (Hypnaceae); and (2) liverworts: one thalloid liverwort (Marchantia emarginata Reinw. Blume \& Nees var. emarginata (Marchantiaceae), and one aquatic leafy liverwort (Porella acutifolia (Lehm. \& Lindenb.) Trevis. var. birmanica S. Hatt. (Porellaceae).

Scopelophila cataractae is a rare taxon found in Thailand that is listed as endangered in the IUCN Red List's threatened category ${ }^{18}$. Few specimens of this moss taxa have been discovered in the forests of Northern Thailand $^{19}$. Scopelophila cataractae is found in various parts of the world including China, Korea, Japan, Papua New Guinea North and South America ${ }^{20,21}$. A protonemal colony of $S$. cataractae was observed at the same period of time (June, during the rainy season) and at the same study site as in the previous study ${ }^{19}$. Narrow, light-green patches of the protonemata occur along the stone base (c. $50 \mathrm{~cm}$ height) in streams, together with colonies of other bryophytes such as $H$. involuta. The colony consisted of numerous filamentous protonema which produced shoots of $S$. cataractae with numerous gemma-like cells on the axils of younger leaves.

Porella acutifolia var. birmanica was firstly discovered in Burma and is mostly distributed in the Indochina regions including Burma, Vietnam, Laos, and Thailand 22,23 . This taxon has been reported in Doi (mountain) Suthep and Ru See (Hermit) cave in Doi Suthep-Pui National Park, Chiang Mai Province, at elevations of about 1,100-1,200 $\mathrm{m}^{22}$. In open and urban environments, Hyophila involuta, Bryum sp., and M. emarginata may be termed pioneer taxa. Hyophila involuta can be located in a variety of habitats including deserts, soil in humid regions, soil, wet rocks, and waterfall stream banks, as well as on concrete buildings in urban settings ${ }^{24,25}$. Unfortunately, Bryum sp. specimen lacked sporophyte materials, thus it was not possible to identify it to the species level. Members of the Bryaceae family, on the other hand, are abundant in urban and disturbed regions across the world, and can be seen growing with potted plants ${ }^{26}$. Marchantia emarginata, a cosmopolitan taxon of thalloid liverwort ${ }^{27}$, is abundant on soils and rocks near stream banks and other locations in Chiang Mai Province, and is not restricted to National Parks. There were three lithophytic mosses, which are aquatic, semi-aquatic, or found on soil and rock near the Huay Pah Lahd falls seasonally dry streams. Ectropothecium zollingeri, F. crispulus var. crispulus, and C. prionophyllum, for example, may thrive on muddy, debris-covered rocks that are inundated during the rainy season and dry during the hot-dry season. Many bryologists have found mosses such as E. zollingeri2 ${ }^{28}$; F. crispulus var. crispulus ${ }^{20}$; and C. prionophyllum ${ }^{29}$ in various moist or semi-wet locations including aquariums.

Heavy metal concentrations in bryophyte tissues and substrates. Bryophytes do not have true roots, stems, and leaves; rather, they possess multicellular rhizoids at the lowest part of the structure, which are responsible for water and nutrient absorption ${ }^{30}$. Bryophyte rhizoids facilitate uptake of available minerals and water to the stems through capillary action. Because bryophytes lack roots, they can readily absorb heavy metals throughout their entire surface of rhizoids ${ }^{31}$. Furthermore, phyllids (leaf-like structure) and thalli of bryophytes have highly absorbent surfaces and an absence of waxy cuticle over the laminal surfaces. As a consequence, cell walls easily absorb moisture and a wide range of minerals and metal ions from the water that flows over the plant $^{32}$. Heavy metal accumulation in bryophyte tissues in this study appear in Table 2. Copper levels in tissue ranged from 8.5 $\mathrm{mg} \mathrm{kg}^{-1}$ ( $P$. acutifolia var. birmanica gametophyte) to $530.1 \mathrm{mg} \mathrm{kg}^{-1}$ (S. cataractae protonema); Cd from $4.8 \mathrm{mg} \mathrm{kg}^{-1}$ ( $E$. zollingeri gametophyte) to $16.9 \mathrm{mg} \mathrm{kg}^{-1}$ (S. cataractae protonema); Zn from $129.4 \mathrm{mg} \mathrm{kg}^{-1}$ (H. involuta gametophyte) to $1,187.2$ $\mathrm{mg} \mathrm{kg}^{-1}$ (S. cataractae protonema); Fe from $3,962.5 \mathrm{mg} \mathrm{kg}^{-1}$ (H. involuta gametophyte) to $8,026.7 \mathrm{mg} \mathrm{kg}^{-1}$ ( $S$. 
cataractae protonema); and $\mathrm{Mn}$ from $143.3 \mathrm{mg} \mathrm{kg}^{-1}$ (S. cataractae gametophyte) to $504.6 \mathrm{mg} \mathrm{kg}^{-1}$ (C. prionophyllum gametophyte).

In this investigation, gametophytes of $S$. cataractae had considerably greater $\mathrm{Cu}$ accumulation $(p<0.05)$ or approximately 3.7-59 $x$ than did other bryophytes, although protonema of $S$. cataractae had a slightly higher Cu concentration than gametophytes of $S$. cataractae $(p>0.05)$. Because it accumulated Cu primarily in gametophyte tissue, $S$. cataractae, often known as "rare Cu moss," is categorized as a hyperaccumulator ${ }^{33}$. Copper is an essential nutrient that is required for plant development and growth. This element plays a significant role in regulating physiological functions such as the photosynthetic and respiratory electron transport chains, nitrogen fixation, protein metabolism, antioxidant production, the ROS defense system, cell wall metabolism, and hormone perception, and acts as an essential cofactor for numerous metalloproteins ${ }^{34}$. At the cellular level, however, excessive $\mathrm{Cu}$ concentrations are harmful to plants because binding to different enzymes results in inactivation and disruption of enzyme activity or protein functions ${ }^{34}$. Gametophytes of $S$. cataractae accumulated substantial amounts of $\mathrm{Cd}, \mathrm{Zn}$ and $\mathrm{Fe}$, with concentrations of $9.2 \mathrm{mg} \mathrm{kg}^{-1}, 846.1 \mathrm{mg} \mathrm{kg}^{-1}$ and $5,434.3 \mathrm{mg} \mathrm{kg}^{-1}$, respectively. $S$. cataractae has been shown to accumulate substantial amounts of different heavy metals such as $\mathrm{Cd}, \mathrm{Cu}$ and $\mathrm{Zn}$ in contaminated soils (e.g., Cu tailings) ${ }^{4}$. Remarkably low Cu concentrations were detected in C. prionophyllum and H. involuta $\left(10.3 \mathrm{~kg}^{-1}\right.$ and $9.6 \mathrm{mg} \mathrm{kg}^{-1}$, respectively).

The highest $\mathrm{Cu}$ concentrations were found in sediment substrate of shoot colonies and protonemal colonies of $S$. cataractae (251.6 mg kg$~^{-1}$ and $239.4 \mathrm{mg} \mathrm{kg}^{-1}$, respectively) $(p<0.05)$, whereas substantial Fe concentrations were found in sediment substrate of gametophyte colonies of $H$. involuta $\left(3,127.1 \mathrm{mg} \mathrm{kg}^{-1}\right)(p<0.05)$ and sediment substrate of protonemal colonies, shoot colonies and decayed moss of $S$. cataractae $\left(2,345.3,2,289.4\right.$ and 1,963.7 $\mathrm{mg} \mathrm{kg}^{-1}$, respectively) (Table 3). Copper concentrations in substrates of $S$. cataractae and water were generally in the following order: sediment substrate $>$ rock $>$ water. According to recent research, growth substrate is a key source of heavy metals in stream environments. This may have led to increased absorption and accumulation of $\mathrm{Al}, \mathrm{Cu}$ and $\mathrm{Zn}$ in $\mathrm{S}$. cataractae gametophytes ${ }^{19}$. Cadmium and $\mathrm{Zn}$ concentrations in rock substrates of $S$. cataractae and $P$. acutifolia var. birmanica were low $\left(0.5\right.$ and $0.3 \mathrm{mg} \mathrm{kg}^{-1}$ for Cd, and 34.9 and $31.2 \mathrm{mg} \mathrm{kg}^{-1}$ for $\mathrm{Zn}$, respectively). Heavy metals ( $\mathrm{Cu}, \mathrm{Fe}$ and $\mathrm{Mn})$ in rock substrates of $P$. acutifolia var. birmanica were found to be similar to in the rock substrates of $S$. cataractae. This comparable distribution of heavy metals in rock substrates may be attributed to the fact that they are located in a similar environment and so receive heavy metals from similar sources and mechanisms. This trend is consistent with the findings of the previous study ${ }^{19}$.

Many bryophyte taxa have been tested for their tolerance and accumulation capabilities at both laboratory and field scales. For example, B. radiculosum Brid. (Bryaceae) grown in industrial areas of Portoscuso (Sardinia, Italy) has been used as bioindicator for trace elements such as $\mathrm{Pb}, \mathrm{Cd}$ and $\mathrm{Zn}$, with accumulation rates at $61-2141 \mathrm{mg} \mathrm{kg}^{-1}, 3-40.6 \mathrm{mg} \mathrm{kg}^{-1}$ and 32-2,360 mg kg-1, respectively ${ }^{35}$. Bryum radiculosum growing in areas which received heavy metals from Cu-containing pesticides in vineyards, accumulated considerably lower amounts of Cu than Bryum sp. in this study (135.3 mg kg ${ }^{-1}$ ), or less than $1.4-13.5$ fold ${ }^{35}$. Furthermore, P. acutifolia var. birmanica, C. prionophyllum and Bryum sp. accumulated substantial Fe $\left(6,877.6 \mathrm{mg} \mathrm{kg}^{-1}\right.$, $6,370 \mathrm{mg} \mathrm{kg}^{-1}$ and 5,869.9 $\mathrm{mg} \mathrm{kg}^{-1}$, respectively), as well as substantial Cd (12 $\mathrm{mg} \mathrm{kg}^{-1}, 8.2 \mathrm{mg} \mathrm{kg}^{-1}$ and $6.2 \mathrm{mg} \mathrm{kg}^{-1}$, respectively), and modest amounts of $\mathrm{Zn}\left(161.3 \mathrm{mg} \mathrm{kg}^{-1}, 226.9 \mathrm{mg} \mathrm{kg}^{-1}\right.$ and $225.5 \mathrm{mg} \mathrm{kg}^{-1}$, respectively). Cadmium is a hazardous metal and Cd exposure in moss media at $10 \mathrm{mM}$ inhibited photosynthesis and caused nutrient deficiencies, which can lead to chlorosis in gametophyte tissues of Physcomitrium patens (Hedw.) Mitt. (Funariaceae) and aquatic moss, Fontinalis antipyretica Hedw. (Fontinalaceae) ${ }^{36}$. Zinc and Fe often occur in high concentrations in the lithosphere. Both are major components of numerous enzymes and proteins in plants and are thus essential for biota. High concentrations of $\mathrm{Zn}$ and $\mathrm{Fe}$, on the other hand, can be toxic to moss cells, affecting the entire plant by decreasing moss growth and development ${ }^{37}$.

In this study, substantial Mn concentrations were detected in gametophytic tissues of $C$. prionophyllum, Bryum sp., $H$. involuta and F. crispulus var. crispulus (504.6 mg kg-1, $482.6 \mathrm{mg} \mathrm{kg}^{-1}, 467.2 \mathrm{mg} \mathrm{kg}^{-1}$ and $448.6 \mathrm{mg} \mathrm{kg}^{-1}$, respectively). Manganese accumulations in the study bryophytes were much higher (144.3-504.6 mg kg-1) when compared to four moss taxa Bryum argenteum Hedw. (Bryaceae), Bryum capillare Hedw. (Bryaceae), Brachythecium sp. (Brachytheciaceae), and Hypnum cupressiforme Hedw. (Hypnaceae) grown in various locations (roadside, populated areas, forests, croplands), with a wide range 
of $\mathrm{Mn}$ accumulation (0.1-8.6 $\left.\mathrm{mg} \mathrm{kg}^{-1}\right)^{38}$. Excessive $\mathrm{Mn}$ concentration in plant tissues can induce oxidative stress, alter enzymatic activity, absorption and accumulation of nutrients, and translocation of certain elements including calcium (Ca), magnesium $(\mathrm{Mg})$, Fe and phosphorus $(P)^{39}$.

The rediscovery of $P$. acutifolia var. birmanica in Huay Pah Lahd stream after a half-century ${ }^{22}$ may suggest that the Doi SuthepPui National Park still serves as a haven for sensitive bryophytes, or it could indicate that the park is minimally affected by anthropogenic activities and thus can support a suitable habitat for bryophytes. However, recent reports suggest that anthropogenic activities around the sampling location may have introduced heavy metals into sediment and water, resulting in increased heavy metal absorption and accumulation in bryophyte tissue ${ }^{19}$. Because $P$. acutifolia var. birmanica also accumulated substantial heavy metals, particularly $\mathrm{Cd}$, the presence of this leafy liverwort may be used as bioindicator in future research for monitoring changes in environmental patterns of stream ecosystems.

Enrichment factors. The EFs of all heavy metals examined (Fig. 1) were very low (<2). For example, the EFs of Cd and Mn in the study site were lower than 12.4 times and 34.5 times those of mosses grown along a major road in Serbia, suggesting that the sources of these metals are lithologic, i.e., sediment, water, and rock ${ }^{40}$. Anthropogenic activities are certainly sources of heavy metals, particularly in locations of domestic dwellings, industry, and other human activities ${ }^{41}$.

Each bryophyte taxon has specific habitat and environmental preferences and a different ecological niche. These factors, in combination with their sensitivity to environmental change, makes bryophyte taxa distribution a useful indicator of vegetation alteration and climate change ${ }^{42}$. Thus, bryophytes are commonly used to evaluate the health status of a habitat, as they have the propensity to take up and accumulate pollutants from soil and water. Many reports have indicated that certain sensitive bryophyte taxa accumulate trace metals $(\mathrm{Cd}, \mathrm{Pb}, \mathrm{Ni}$, and $\mathrm{Cr}$ ) from the atmosphere, soil and water in contaminated areas across many regions worldwide ${ }^{43}$. Unfortunately, to date, there exist few studies investigating bryophytes as bioindicators of the heavy metals in both terrestrial and aquatic environments in Thailand ${ }^{19}$.

\section{Conclusions}

The presence of bryophytes in terrestrial and aquatic ecosystems has received increasing attention in recent decades, as they play an important role in healthy habitats including nutrient, water, heavy metal and carbon cycling; soil formation; and successional processes. The EFs (all heavy metals $<2$ ) indicated that bryophytes from the study site were enriched with low concentrations of heavy metals due to natural processes; however, anthropogenic activities, e.g., nearby tourist and community activities, may have an impact on increased heavy metal content in the future. This is the first report to show the heavy metal accumulating capacity of bryophyte communities. Furthermore, S. cataractae accumulated more $\mathrm{Cu}, \mathrm{Cd}, \mathrm{Zn}$ and Fe than other bryophyte taxa, suggesting that it might be the best bioindicator in this aquatic environment.

\section{Declarations}

\section{Acknowledgements}

We thank the head and staffs of Doi Suthep-Pui National Park for logistic assistance. Thanks also to the Department of National Parks, Wildlife and Plant Conservation of Thailand for permission to collect specimens.

\section{Author contributions}

N.P. and W.M. developed the concept, planned the experiments, collected the data, performed the statistical analysis and interpreted the findings of this study. N.P. identified all bryophyte taxa and wrote the first draft of the manuscript. W.M. reviewed, revised and approved the final manuscript numerous times. All authors helped in revising the manuscript.

\section{Funding}

This research work was partially supported by Chiang Mai University. 


\section{Completing interests}

The authors declare that they have no completing interests.

\section{References}

1. Gheorghe, S. et al.Metals toxic effects in aquatic ecosystems: Modulators of water quality (IntechOpen, 2017).

2. Galib, S. M. et al. Municipal wastewater can result in a dramatic decline in freshwater fishes: a lesson from a developing country. Knowl. Manag. Aquat. Ecosyst.419, 37. https://doi.org/10.1051/kmae/2018025 (2018).

3. Hussen, A. M. E. A., Retnaningdyah, C., Hakim, L. \& Soemarno, S. The variations of physical and chemical water quality in Coban Rondo waterfall, Malang Indonesia. In The $9^{\text {th }}$ International Conference on Global Resource Conservation (ICGRC) and AJI from Ritsumeikan University 1-11 (2019).

4. Boquete, M. T., Lang, I., Weidinger, M., Richards, C. L. \& Alonso, C. Patterns and mechanisms of heavy metal accumulation and tolerance in two terrestrial moss species with contrasting habitat specialization. Environ. Exp. Bot. 182, 104336. https://doi.org/10.1016/j.envexpbot.2020.104336 (2021).

5. Bonanno, G., Borg, J. A. \& Martino, V. D. Levels of heavy metals in wetland and marine vascular plants and their biomonitoring potential: A comparative assessment. Sci. Total Environ.576, 796-806 (2017).

6. Savatenalinton, S. \& Segers, H. Rotifers of waterfall mosses from Phu Hin Rong Kla National Park, Thailand with the description of Lecane martensi, new species (Rotifera: Monogononta: Lecanidae). Raffles Bull. Zool.56(2), 245-249 (2008).

7. Da Silva, A. S. M., Pôrto, K. C. \& Simabukuro, E. A. Effects of light and nutrients on different germination phases of the cosmopolitan moss Bryum argenteum Hedw. (Bryaceae). Braz. Arch. Biol. Technol.53(4), 763-769 (2010).

8. Dodds, W. K. \& Smith, V. H. Nitrogen, phosphorus, and eutrophication in streams. Inland Waters 6, 155-164 (2016).

9. WHO. Guidelines for Drinking Water Quality. (2004).

10. Liu, M., Sui, X., Hu, Y. \& Feng, F. Microbial community structure and the relationship with soil carbon and nitrogen in an original Korean pine forest of Changbai Mountain, China. BMC Microbiol.19, 218. https://doi.org/10.1186/s12866-019-15846 (2019).

11. Kaur, P. Total solids occurring in various industries effluent water present in Durg district. Curr. World Environ.3(1), 157-160 (2008).

12. Sidibe, A. M., Lin, X. \& Koné, S. Assessing groundwater mineralization process, quality, and isotopic recharge origin in the Sahel Region in Africa. Water11, 789. https://doi:10.3390/w11040789 (2019).

13. Emmanuel, E., Simon, Y. \& Joseph, O. Characterization of hardness in the groundwater of Port-Au-Prince. An overview on the health significance of magnesium in the drinking water. J. Int. Hydrol. Progr. Lat. Am. Caribb.5(2), 35-43 (2013).

14. Brown, G. E., Foster, A. L. \& Ostergren, J. D. Mineral surfaces and bioavailability of heavy metals: A molecular-scale perspective. Proc. Natl. Acad. Sci. USA96, 3388-3395 (1999).

15. Aimphan, D. et al. Recreational carrying capacity in terms of waterfalls quality of Phu Kradueng National Park. Final Report (2012).

16. Tenebe IT et al. A laboratory assessment of the effect of varying roughness on dissolved oxygen using error correction method. Cogent Eng.5(1), 1427191. https://doi.org/10.1080/23311916.2018.1427191 (2018).

17. Kwak, J., Khang, B., Kim, E. \& Kim, H. Estimation of biochemical oxygen demand based on dissolved organic carbon, UV absorption, and fluorescence measurements. J. Chem. Article ID 243769. http://dx.doi.org/10.1155/2013/243769 (2013).

18. Hodgetts, N. et al. A miniature world in decline: European red list of mosses, liverworts and hornworts. (International Union for Conservation of Nature and Natural Resources, 2019).

19. Printarakul, N. \& Meeinkuirt, W. Heavy metal accumulation and copper localization in Scopelophila cataractae in Thailand. Bull. Environ Contam. Toxicol.107, 530-536 (2021).

20. Li XJ, He S \& Iwatsuki, Z. Pottiaceae. In Moss Flora of China (ed He, S) 114-249(Science Press and Missouri Botanical Garden Press, 2001). 
21. Zander, R. H. Pottiaceae Schimpr. Flora North Am.27, 485 (2007).

22. Hattori, S. Studies of the Asiatic species of the genus Porella (Hepaticae). III. J. Hattori Bot. Lab.33, 41-87 (1970).

23. Hattori, S. Studies on the Asiatic species of the genus Porella (Hepaticae). VII. A synopsis of Asiatic Porellaceae. J. Hattori Bot. Lab.44, 91-120 (1978).

24. Eddy, A. A. Handbook of Malesian Mosses, 2. Leucobryaceae to Buxbaumiaceae. (1990).

25. Deora, V. \& Deora, G. S. Morphotaxonomical studies on some mosses of Indian thar desert. Ann. Plant Sci.6(12), 1893-1897 (2017).

26. Floyed, A. \& Gibson, M. Bryophytes of urban industrial streetscapes in Victoria, Australia. Vic. Nat.129(6), 203-214 (2012).

27. Siregar, E., Hannum, S. \& Pasaribu, N. Lejeuneaceae (Marchantiophyta) of Sicike-cike natural park, North Sumatra Indonesia. Taiwania62(4), 356-362 (2014).

28. Shevock, J. R., Ma, W. \& Akiyama, H. Diversity of the rheophytic condition in bryophytes: field observations from multiple continents. Bryol. Divers. Evol.39(1), 75-93 (2017).

29. Wu, P. C., Wang, M. Z. \& Zhong, B. G. Thuidiaceae. In Moss flora of China (ed He, S.) 150-207 (Science Press, and Missouri Botanical Garden Press, 2002).

30. Jones, V. A. S. \& Dolan, L. The evolution of root hairs and rhizoids. Ann. Bot.110, 205-212 (2012).

31. Degola, F. et al. A Cd/Fe/Znresponsive phytochelatin synthase is constitutively present in the ancient liverwort Lunularia cruciata (L.) Dumort. Plant Cell Physiol.55, 1884-1891 (2014).

32. Koz, B. \& Cevik, U. Lead adsorption capacity of some moss species used for heavy metal analysis. Ecol. Indic.36, 491-494 (2014).

33. Nomura, T. \& Hasezawa, S. Regulation of gemma formation in the copper moss Scopelophila cataractae by environmental copper concentrations. J. Plant Res.124, 631-638 (2011).

34. Yruela, I. Copper in plants. Braz. J. Plant Physiol.17, 145-146 (2005).

35. Schintu, M., Cogoni, A., Durante, L., Cantaluppi, C. \& Contu, A. Moss (Bryum radiculosum) as a bioindicator of trace metal deposition around an industrialised area in Sardinia (Italy). Chemosphere60, 610-618 (2005).

36. Bellini, E., Betti, C. \& Di Toppi, L. S. Responses to cadmium in early-diverging Streptophytes (Charophytes and Bryophytes): Current views and potential applications. Plants10(4), 770. https://doi:10.3390/plants10040770 (2021).

37. Dos Santos, R. S., De Araujo Júnior, A. T., Pegoraro, C. \& De Oliveira, A. C. Dealing with iron metabolism in rice: from breeding for stress tolerance to biofortification. Genet. Mol. Biol. 40(Suppl 1), 312-325 (2017).

38. Vukojević, V. et al. Determination of heavy metal deposition in the country of Obrenovac (Serbia) using mosses as bioindicators. IV. Manganese (Mn), molypdenum (Mo), and nickel (Ni). Arch. Biol. Sci. Belgrade61(4), 835-845 (2009).

39. Millaleo, R., Reyes-Diaz, M., Ivanov, A. G., Mora, M. L. \& Alberdi, M. Manganese as essential and toxic element for plants: Transport, accumulation and resistance mechanisms. J. Soil Sci. Plant Nutr.10(4), 470-481 (2010).

40. Dragović, \& Mihailović, N. Analysis of mosses and top soils for detecting sources of heavy metal pollution: multivari- ate and enrichment factor analysis. Environ. Monit. Assess. 157(1-4), 383-390 (2009).

41. Zarazúa-Ortega, G. et al. Assessment of spatial variability of heavy metals in metropolitan zone of Toluca Valley, Mexico using the biomonitoring technique in mosses and TXRF Analysis. Sci World J. https://doi:10.1155/2013/426492 (2013).

42. Song, S. et al. Impacts of environmental heterogeneity on moss diversity and distribution of Didymodon (Pottiaceae) in Tibet, China. PLoS ONE10(7), e0132346. https://doi:10.1371/journal.pone.0132346 (2015).

43. Mazzoni, A. C., Lanzer, R., Bordin, J., Schäfer, A. \& Wasum, R. Mosses and indicators of atmospheric metal deposition in an industrial area of southern Brazil. Acta Bot. Bras.26(3), 553-558 (2012).

44. Fernández, J. A., Boquete, M. T., Carballeira, A. \& Aboal, J. R. A critical review of protocols for moss biomonitoring of atmospheric deposition: sampling and sample preparation. Sci. Total Environ.517, 132-150 (2015).

45. Eddy, A. A handbook of Malesian mosses. Volume 3. Splachnobryaceae to Leptostomataceae (HMSO, 1996).

46. Gradstein, S. B. Guide to the liverworts and hornworts of Java (SEAMEO BRYOTROP, 2011). 
47. Zhang, M. X. \& He, S. Hypnaceae. In Moss flora of China (ed He, S.) 80-260 (Science Press, and Missouri Botanical Garden Press, 2005).

48. APHA AWWA and WEF (American Public Health Association, American Water Works Association and Water Environment Federation). Standard Methods for the Examination of Water and Wastewater (American Public Health Association, 2005).

49. Macedo-Miranda, G. et al. Accumulation of heavy metals in mosses: a biomonitoring study. SpringerPlus5,

715. https://doi:10.1186/s40064-016-2524-7 (2016).

\section{Tables}

Table 1. Physicochemical properties of Pah Lahd stream

\begin{tabular}{lll}
\hline Parameter & Unit & Concentration \\
\hline Total hardness & $\mathrm{mg} \mathrm{L}^{-1} \mathrm{CaCO}^{3}$ & 31.7 \\
Total solids & $\mathrm{mg} \mathrm{L}^{-1}$ & 103 \\
Fluoride $\left(\mathrm{F}^{-}\right)$ & $\mathrm{mg} \mathrm{L}^{-1}$ & $<0.15$ \\
Ammonia-nitrogen $\left(\mathrm{NH}_{3}{ }^{-}{ }^{-\mathrm{N}}\right)$ & $\mathrm{mg} \mathrm{L}^{-1}$ & $\mathrm{ND}$ \\
Phosphate $\left(\mathrm{PO}_{4}{ }^{3]}\right)$ & & \\
Chloride $\left(\mathrm{Cl}^{-}{ }^{-}\right)$ & $\mathrm{mg} \mathrm{L}^{-1}$ & 6.2 \\
Nitrate-nitrogen $\left(\mathrm{NO}_{3}{ }^{-}{ }^{-\mathrm{N})}\right.$ & $\mathrm{mg} \mathrm{L}^{-1}$ & 1.01 \\
Total Kjeldahl nitrogen (TKN) & $\mathrm{mg} \mathrm{L}^{-1}$ & $<4.0$ \\
Total organic carbon (TOC) & $\mathrm{mg} \mathrm{L}^{-1}$ & $\mathrm{ND}$ \\
Biological oxygen demand (BOD) & $\mathrm{mg} \mathrm{L}^{-1}$ & $<1.0$ \\
Dissolved oxygen (DO) & $\mathrm{mg} \mathrm{L}^{-1}$ & 5.03 \\
Temperature & ${ }^{\circ} \mathrm{C}^{-1}$ & 25.3 \\
pH & & 6.75 \\
Depth & $\mathrm{m}$ & $0.4-1$ \\
\hline
\end{tabular}

Table 2 Heavy metal accumulation in bryophyte tissues $(n=3)$

\section{Families Botanical names Plant part}

\begin{tabular}{|c|c|c|c|c|c|c|c|c|}
\hline \multirow[t]{2}{*}{ Families } & \multicolumn{2}{|c|}{ Botanical names } & \multirow[t]{2}{*}{ Plant part } & \multicolumn{5}{|c|}{ Heavy metal accumulation ( $\mathrm{mg} \mathrm{kg}^{-1}$ ) } \\
\hline & & & & $\mathrm{Cu}$ & $\mathrm{Cd}$ & $\mathrm{Zn}$ & $\mathrm{Fe}$ & Mn \\
\hline Pottiaceae & S. cataractae & & $\begin{array}{l}\text { Gametophyte } \\
\text { (without } \\
\text { protonema) }\end{array}$ & $506.0 \pm 0.6 \mathrm{~b}$ & $9.2 \pm 0.1 \mathrm{c}$ & $846.1 \pm 48.0 \mathrm{~b}$ & $5434.3 \pm 42.6 \mathrm{de}$ & $144.3 \pm 3.5 \mathrm{~d}$ \\
\hline Pottiaceae & S. cataractae & & Protonema & $530.1 \pm 25.8 a$ & $16.9 \pm 0.5 a$ & $1187.2 \pm 393.6 a$ & $8026.7 \pm 164.0 \mathrm{a}$ & $144.5 \pm 0.0 \mathrm{~d}$ \\
\hline Porellaceae & $\begin{array}{l}P . \\
\text { acutifolia var. birm }\end{array}$ & nica & Gametophyte & $8.5 \pm 2.3 \mathrm{~d}$ & $12.0 \pm 1.8 \mathrm{~b}$ & $161.3 \pm 2.8 \mathrm{c}$ & $6877.6 \pm 479.5 b$ & $383.3 \pm 36.9 \mathrm{c}$ \\
\hline Pottiaceae & H. involuta & & Gametophyte & $9.6 \pm 1.9 \mathrm{~d}$ & $5.2 \pm 0.6 \mathrm{~d}$ & $129.4 \pm 4.6 \mathrm{c}$ & $3962.5 \pm 146.5 f$ & $467.2 \pm 12.0 \mathrm{ab}$ \\
\hline Marchantiaceae & $\begin{array}{l}\text { M. emarginata } \\
\text { emarginata }\end{array}$ & var. & Thallus & $23.7 \pm 1.4 \mathrm{~d}$ & $8.7 \pm 0.3 \mathrm{c}$ & $203.2 \pm 17.4 \mathrm{c}$ & $4264.7 \pm 111.9 f$ & $341.9 \pm 23.6 c$ \\
\hline Fissidentaceae & $\begin{array}{l}F . \quad \text { crispulus } \\
\text { crispulus }\end{array}$ & var. & Gametophyte & $24.2 \pm 4.0 \mathrm{~d}$ & $8.2 \pm 0.8 \mathrm{c}$ & $197.6 \pm 0.2 \mathrm{c}$ & $5386.0 \pm 171.3 \mathrm{e}$ & $448.6 \pm 25.2 b$ \\
\hline Leskeaceae & C. prionophyllum & & Gametophyte & $10.3 \pm 3.2 \mathrm{~d}$ & $8.2 \pm 2.0 \mathrm{c}$ & $226.9 \pm 26.6 \mathrm{c}$ & $6370.0 \pm 371.6 \mathrm{c}$ & $504.6 \pm 22.9 a$ \\
\hline Hypnaceae & E. zollingeri & & Gametophyte & $18.2 \pm 3.0 \mathrm{~d}$ & $4.8 \pm 1.0 \mathrm{~d}$ & $140.9 \pm 8.3 c$ & $4391.3 \pm 87.5 f$ & $354.2 \pm 18.4 \mathrm{c}$ \\
\hline Bryaceae & Bryum sp. & & Gametophyte & $135.3 \pm 21.2 \mathrm{c}$ & $6.2 \pm 1.3 \mathrm{~d}$ & $225.5 \pm 16.7 \mathrm{c}$ & $5869.9 \pm 273.6 \mathrm{~d}$ & $482.6 \pm 66.1 \mathrm{ab}$ \\
\hline
\end{tabular}

For each parameter, values followed by different letters indicate significant difference at 5\% probability level

$\mathrm{Cu}$ copper, $\mathrm{Cd}$ cadmium, $\mathrm{Zn}$ zinc, $\mathrm{Fe}$ iron, $\mathrm{Mn}$ manganese

Table 3. Heavy metal accumulation in bryophyte substrates $(n=3)$

For each parameter, values followed by different letters indicate significant difference at $5 \%$ probability level

$\mathrm{Cu}$ copper, $\mathrm{Cd}$ cadmium, $\mathrm{Zn}$ zinc, $\mathrm{Fe}$ iron, $\mathrm{Mn}$ manganese 


\begin{tabular}{|c|c|c|c|c|c|}
\hline \multirow[t]{2}{*}{ Material } & \multicolumn{5}{|c|}{ Heavy metal accumulation ( $\mathrm{mg} \mathrm{kg}^{-1}$ ) } \\
\hline & $\mathrm{Cu}$ & $\mathrm{Cd}$ & $\mathrm{Zn}$ & $\mathrm{Fe}$ & Mn \\
\hline Decayed Cu moss & $188.4 \pm 8.4 b$ & $1.9 \pm 0.3 \mathrm{a}$ & $80.5 \pm 5.7 \mathrm{~b}$ & $1963.7 \pm 99.7 \mathrm{bc}$ & $246.9 \pm 2.3 \mathrm{ab}$ \\
\hline $\begin{array}{l}\text { Sediment substrate of shoot colony of } S \text {. } \\
\text { cataractae }\end{array}$ & $251.6 \pm 35.2 \mathrm{a}$ & $1.5 \pm 0.1 \mathrm{bcd}$ & $59.3 \pm 4.3 \mathrm{c}$ & $2289.4 \pm 363.3 b$ & $143.9 \pm 28.9 \mathrm{~cd}$ \\
\hline $\begin{array}{l}\text { Sediment substrate of protonemal colony } \\
\text { of } S \text {. cataractae }\end{array}$ & $239.4 \pm 1.4 \mathrm{a}$ & $1.7 \pm 0.3 \mathrm{ab}$ & $65.9 \pm 6.3 \mathrm{c}$ & $2345.3 \pm 298.4 b$ & $126.4 \pm 3.0 \mathrm{~d}$ \\
\hline Rock substrate of $S$. cataractae & $56.3 \pm 4.3 \mathrm{c}$ & $0.5 \pm 0.2 f$ & $34.9 \pm 1.3 \mathrm{~d}$ & $1259.9 \pm 16.9 \mathrm{~d}$ & $243.4 \pm 38.6 b c$ \\
\hline $\begin{array}{l}\text { Rock substrate of } P \text {. acutifolia } \\
\text { var. birmanica }\end{array}$ & $51.2 \pm 15.6 \mathrm{c}$ & $0.3 \pm 0.2 f$ & $31.2 \pm 4.7 \mathrm{~d}$ & $1234.9 \pm 40.1 \mathrm{~d}$ & $202.6 \pm 76.6 b c$ \\
\hline $\begin{array}{l}\text { Sediment substrate of shoot colony of } H \text {. } \\
\text { involuta }\end{array}$ & $11.2 \pm 0.9 \mathrm{~d}$ & $1.7 \pm 0.2 \mathrm{abc}$ & $122.6 \pm 0.7 \mathrm{a}$ & $3127.1 \pm 312.0 \mathrm{a}$ & $314.5 \pm 8.5 \mathrm{a}$ \\
\hline $\begin{array}{l}\text { Sediment substrate of shoot colony of } M \text {. } \\
\text { emarginata var. emarginata }\end{array}$ & $55.6 \pm 1.7 \mathrm{c}$ & $1.2 \pm 0.0 \mathrm{de}$ & $66.2 \pm 1.2 \mathrm{c}$ & $1174.3 \pm 2.1 \mathrm{~d}$ & $297.7 \pm 12.9 a$ \\
\hline $\begin{array}{l}\text { Sediment substrate of shoot colony of } F \text {. } \\
\text { crispulus var. crispulus }\end{array}$ & $57.5 \pm 4.2 \mathrm{c}$ & $1.2 \pm 0.1 \mathrm{de}$ & $66.8 \pm 3.1 \mathrm{c}$ & $1172.8 \pm 8.1 \mathrm{~d}$ & $312.0 \pm 14.3 \mathrm{a}$ \\
\hline $\begin{array}{l}\text { Sediment substrate of shoot colony of } C \text {. } \\
\text { prionophyllum }\end{array}$ & $54.5 \pm 4.1 \mathrm{c}$ & $1.2 \pm 0.1 \mathrm{de}$ & $64.9 \pm 3.3 \mathrm{c}$ & $1164.5 \pm 16.3 d$ & $301.4 \pm 18.4 \mathrm{a}$ \\
\hline $\begin{array}{l}\text { Sediment substrate of shoot colony of } E \text {. } \\
\text { zollingeri }\end{array}$ & $60.8 \pm 0.4 \mathrm{c}$ & $1.3 \pm 0.0 \mathrm{cde}$ & $76.3 \pm 5.8 b$ & $1663.7 \pm 99.8 \mathrm{c}$ & $312.0 \pm 23.5 a$ \\
\hline $\begin{array}{l}\text { Sediment substrate of shoot colony of } \\
\text { Bryum sp. }\end{array}$ & $56.5 \pm 6.3 \mathrm{c}$ & $1.0 \pm 0.1 \mathrm{e}$ & $62.7 \pm 0.8 \mathrm{c}$ & $1156.6 \pm 12.3 d$ & $273.3 \pm 29.3 \mathrm{ab}$ \\
\hline
\end{tabular}

\section{Figures}

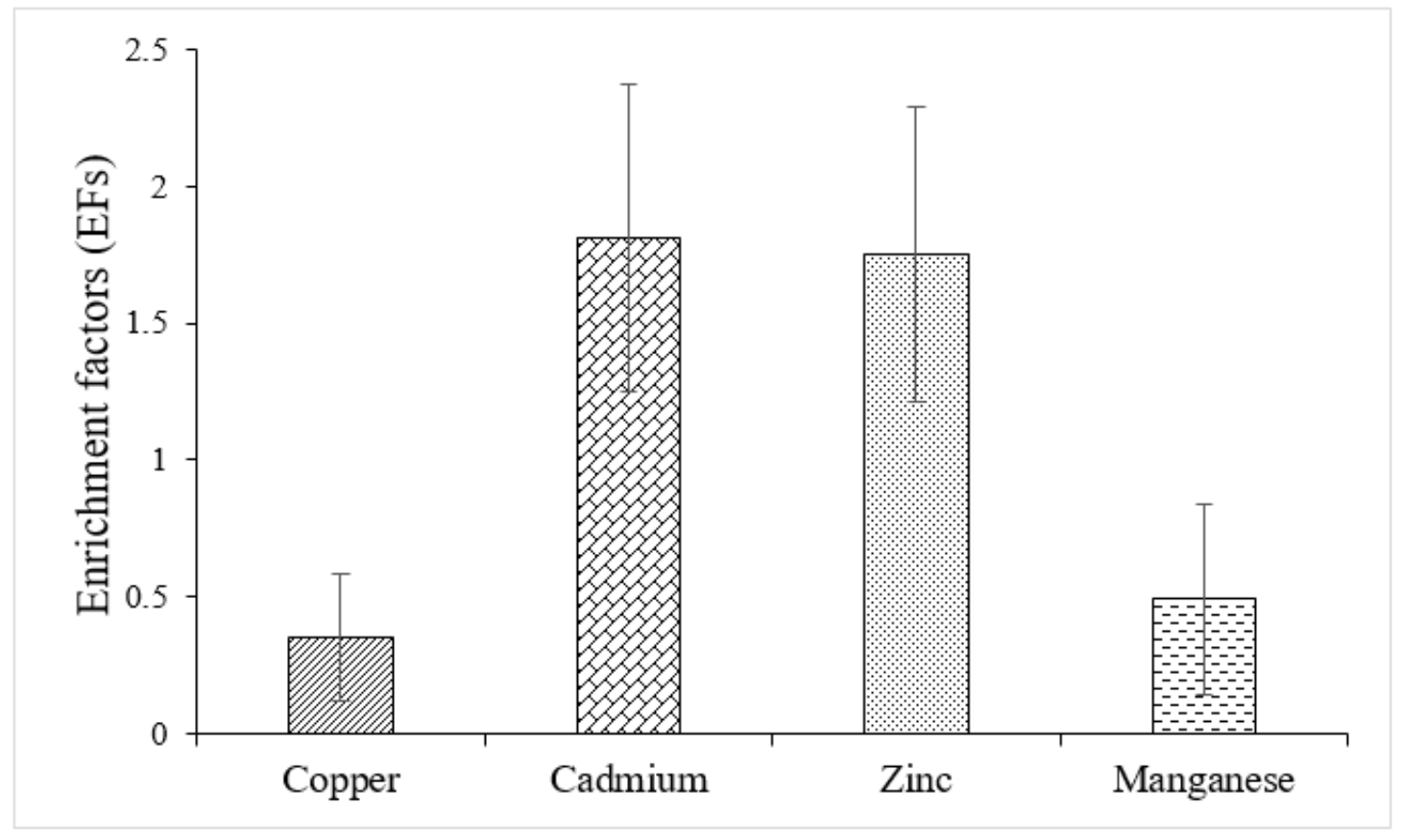

Figure 1

Means for the enrichment factors (EFs) with corresponding standard deviations (SD) for four elements in mosses relative to the sediment substrate 